\title{
Correlations between Wind Power Density and Different Meteorological Parameters in Nineveh Governorate
}

\author{
Waleed I . AL-Rijabo ${ }^{*} \quad$ Fatin M. Hamam ${ }^{* *}$ \\ *Department of Physics/ College of Education for Pure Science/ University of Mosul \\ **Department of Basic Science/ College of Dentistry/University of Mosul
}

(Received 28/6/2018; Accepted 10/10/2018)

\begin{abstract}
The aim of this paper is to estimate the mean monthly values of wind power density in four meteorological stations in Nineveh Governorate (Mosul, Rabea, Talafar, Sinjar) for the period (1980 - 2010) using different meteorological parameters. Five different models (Linear, Quadratic, Logarithmic, Linear Logarithmic, power) were used to estimate the wind power density. The performance of this regression models were evaluated. Several statistical test were used to control the validation and goodness of the regression models in terms of ( $R, R^{2}$, MAE, RMSE). Linear model gave the best fit for the relation between WPD and (P, n, H, C) in all stations. Quadratic model and Linear model gave the best fit between WPD and (Rad. RH, T) in all stations. Logarithmic model give the best fit between WPD and Rad in Mosul station.
\end{abstract}

Keywords: Wind Power Density, Correlations, meteorological, parameters wind energy, clean energy.

علافل الرتبلا بين كثلة قدرة الرباح والعناهر الانوائية المختالفة فححلغلة نينوى

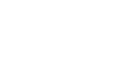

الهذف من هذه الدرلسة هي للتنبؤ بقيم المعدلات الثهرية لكثافة قدرة الرياح لأريعمطظلت انوائية في محاظظ ــة نيذ -وى وهي (الموصل، ربيعة،سنجار، تلعفر) للفترة الزمنية من (1980 - 2010) بلستخدله عناصر النوائية مختلفة. وت م لـ الد تخدلم خمسة نماذج رياضية (Linear, Quadratic, Logarithmic, Linear Logarithmic, power) لتخمين كثافة قدرة الرياح. Linear model . (R, R², MAE, RMSE) ومة لستخدلم عدة لختبارك لحصائية لإيجاد القيم الجية والمنلد بة لح سلبة

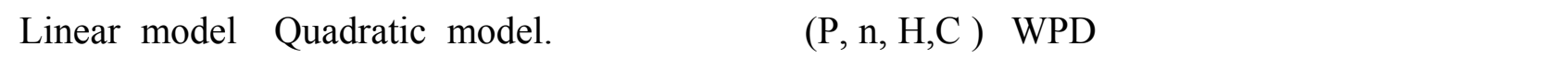
اعلى قيماً جيدة لعلاقة الارتبط بين WPD و (Rad. RH, T) في كل المعطلت Logarithmic model. أعطى قيماً جيدة لعلاقة الارتبط بين WPD و Rad فتط في معطة الموصل.

الهاملت الدالة: كثافة قدرة الرياح، علاقلت الارتبط، العناصر الانوائية،طاقة الرياح، الطاقة الظيفة.

INTRODUCTION

Among the sources of renewable energy, wind energy is the most common and fastest growing energy technology in terms of percentage of yearly growth of installed capacity (Ohnakin, 2010). The potential benefits of wind power are a clean, renewable and economic energy source. Wind resources are seldom consistent and vary with time of the day, season of the year, height above the 
ground, type of terrain and from year to year, hence should be investigated carefully and completely (Rehmam, 2013).

Wind energy potential assessment is critical factors for suitable development of wind power application at a given location (Kidmo, 2015). Some parameters are important in determining power extracted from wind turbine such as:

Wind velocity, relative humidity, pressure, air density, rain, dust and temperature (Klumpner, 2011, Barthlmin, 2010, Perkevic, 2013).

Air temperature affects extracted power from wind, this effect is dependent on the altitude and the value of air temperature (Abdul Kareem, 2015). The humidity is also an important variable that effect on the wind power (Nolan, 2011).

In this paper correlations are proposed for the mean values of Wind Power Density (WPD) for (Mosul, Rabea, Sinjar, Talafr) stations in Nineveh Governorate based on meteorological parameters for the period (1980-2010).

\section{THEORTICAL}

Mean monthly values of the different meteorological paramrters (total solar radiation, sunshine duration, relative humidity, air temperature, wind speed, cloudiness, pressure) were obtained from Iraqi meteorological organization for the period (1980 - 2010) for (Mosul, Rabea, Sinjar, Talafr) stations.

The geographical coordinate of the four stations were listed in (Table 1).

Fig. (1) shows the locations of the four stations in Nineveh Governorate.

Table 1: Geographical coordinates of the four meteorological stations in Ninava Governorate

\begin{tabular}{|c|c|c|c|}
\hline Stations & Latitude & Longitude & Elevation(m) \\
\hline Mosul & $36^{\circ} 19^{\prime}$ & $43^{\circ} 09^{\prime}$ & 223 \\
\hline Telafar & $36^{\circ} 22^{\prime}$ & $42^{\circ} 28^{\prime}$ & 273 \\
\hline Sinjar & $36^{\circ} 19^{\prime}$ & $41^{\circ} 50^{\prime}$ & 465 \\
\hline Rabea & $36^{\circ} 48^{\prime}$ & $42^{\circ} 06^{\prime}$ & 382 \\
\hline
\end{tabular}

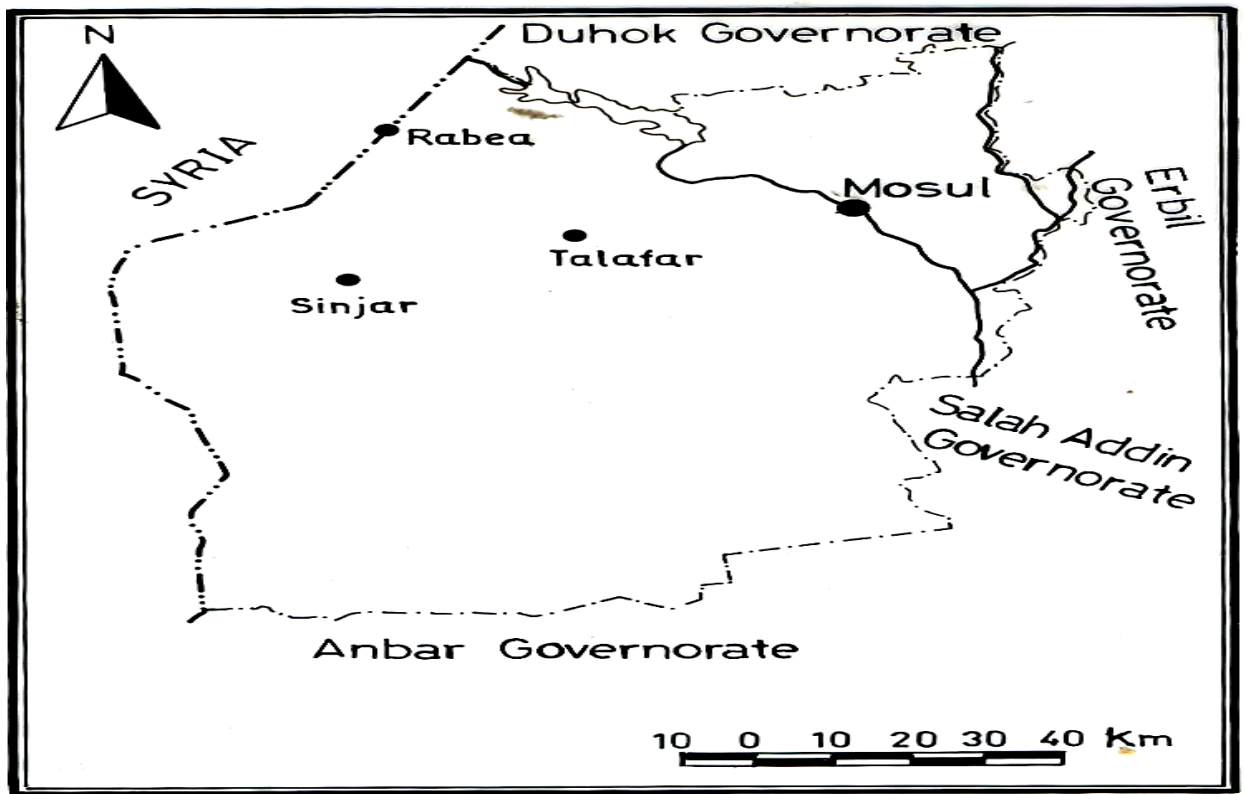

Fig. 1: Location of the four meteorological stations in Ninava Governorate

Tables $(2,3,4,5)$ show the values of the mean monthly meteorological parameters in all stations during the period $(1980-2010)$. 
Table 2: Mean Monthly values of meteorological parameters and Wind Power Density for Mosul station at 10m height for the period (1980- 2010)

\begin{tabular}{|c|c|c|c|c|c|c|c|c|c|c|c|c|}
\hline $\begin{array}{c}\text { Mon. } \\
\text { Met. el . }\end{array}$ & JAN & FEB & MAR & APR & MAY & JUN & JUL & AUG & SEP & OCT & NOV & DEC \\
\hline WPD(w/m $\left.{ }^{2}\right)$ & 0.6 & 1.3 & 1.7 & 2 & 3.5 & 3.5 & 3 & 2 & 0.8 & 0.4 & 0.3 & 0.6 \\
\hline V(m/s) & 1 & 1.3 & 1.4 & 1.5 & 1.8 & 1.8 & 1.7 & 1.5 & 1.1 & 0.9 & 0.8 & 1 \\
\hline Sun shine(hr) & 4.7 & 5.6 & 6.8 & 7.9 & 9.9 & 12.2 & 11.9 & 11.3 & 10.3 & 8.1 & 6.4 & 4.6 \\
\hline Pressure(mb) & 1021.3 & 1019 & 1015 & 1013 & 1010 & 1004 & 999.6 & 1001.6 & 1008.4 & 1014.6 & 1019 & 1021 \\
\hline Tmean(C $)$ & 6.9 & 8.7 & 12.9 & 18.1 & 24.7 & 31.2 & 34.6 & 33.8 & 28.7 & 21.7 & 13.6 & 8.7 \\
\hline RH\% & 79 & 74 & 68 & 62 & 43 & 28 & 25 & 27 & 31 & 46 & 65 & 78 \\
\hline Radation & 1850 & 2700 & 3500 & 4478 & 5528 & 6027 & 5960 & 5444 & 4684 & 3277 & 2301 & 1690 \\
\hline Cloud(octa) & 4.3 & 4.2 & 3.9 & 3.8 & 2.7 & 0.9 & 0.4 & 0.3 & 0.6 & 2.4 & 3 & 4.3 \\
\hline
\end{tabular}

Table 3: Mean Monthly values of meteorological parameters and Wind Power Density for Rabea station at 10m height for the period (1980- 2010)

\begin{tabular}{|c|c|c|c|c|c|c|c|c|c|c|c|c|}
\hline $\begin{array}{c}\text { Mon. } \\
\text { Met. el . }\end{array}$ & JAN & FEB & MAR & APR & MAY & JUN & JUL & AUG & SEP & OCT & NOV & DEC \\
\hline WPD(w/m $\left.{ }^{2}\right)$ & 2.5 & 3 & 3.5 & 3.5 & 5.6 & 5.6 & 5.6 & 4.8 & 3.5 & 2.5 & 1.7 & 1.7 \\
\hline $\mathrm{V}(\mathrm{m} / \mathrm{s})$ & 1.6 & 1.7 & 1.8 & 1.8 & 2.1 & 2.1 & 2.1 & 2 & 1.8 & 1.6 & 1.4 & 1.4 \\
\hline $\begin{array}{c}\text { Sun } \\
\text { shine(hr) }\end{array}$ & 4.6 & 5 & 6.4 & 7.9 & 9.8 & 12.2 & 12.3 & 11.5 & 10 & 8 & 5.9 & 6.4 \\
\hline Pressure(mb) & 1020 & 1017 & 1014.5 & 1012 & 1008.6 & 1003.5 & 999.3 & 1001 & 1007 & 1014 & 1018 & 1020.7 \\
\hline Tmean(C $)$ & 5.5 & 7 & 10.4 & 15.8 & 22.6 & 28.9 & 32.4 & 31.5 & 26.8 & 20.4 & 12.6 & 7.5 \\
\hline RH\% & 80 & 76 & 70 & 66 & 50 & 32.7 & 30 & 31 & 33 & 47 & 69 & 81 \\
\hline Radation & 1863 & 2411 & 3388.7 & 4368 & 5283 & 6115.8 & 6053.8 & 5518 & 4629 & 3246.7 & 2231 & 2050 \\
\hline Cloud(octa) & 4 & 4.1 & 4 & 3.6 & 2.6 & 1.34 & 0.9 & 0.6 & 1.2 & 2.45 & 3.3 & 4.3 \\
\hline
\end{tabular}

Table 4: Mean Monthly values of meteorological parameters and Wind Power Density for Sinjar station at $10 \mathrm{~m}$ height for the period (1980 - 2010)

\begin{tabular}{|c|c|c|c|c|c|c|c|c|c|c|c|c|}
\hline $\begin{array}{c}\text { Mon. } \\
\text { Met.el . }\end{array}$ & JAN & FEB & MAR & APR & MAY & JUN & JUL & AUG & SEP & OCT & NOV & DEC \\
\hline $\mathrm{WPD}\left(\mathrm{w} / \mathrm{m}^{2}\right)$ & 4.2 & 7.4 & 18.3 & 19.8 & 38.7 & 51.5 & 51.5 & 38.7 & 21.7 & 6.4 & 3 & 3 \\
\hline $\mathrm{V}(\mathrm{m} / \mathrm{s})$ & 1.9 & 2.3 & 2.8 & 3.2 & 4 & 4.4 & 4.4 & 4 & 3.3 & 2.2 & 1.7 & 1.7 \\
\hline $\begin{array}{c}\text { Sun } \\
\text { shine(hr) }\end{array}$ & 4.9 & 5.6 & 6.6 & 7.6 & 9.1 & 11.7 & 11.9 & 11.4 & 10.3 & 8.4 & 6 & 5 \\
\hline Pressure(mb) & 1020.5 & 1018.6 & 1015 & 1012 & 1009 & 1004 & 999.4 & 1000.6 & 1007.3 & 1014 & 1019 & 1020 \\
\hline $\operatorname{Tmean}\left(\mathrm{C}^{\circ}\right)$ & 7 & 8.7 & 13 & 18.6 & 25.2 & 31.3 & 35 & 34.4 & 30.1 & 23.8 & 14.8 & 9.5 \\
\hline RH $\%$ & 65.4 & 62 & 55.2 & 47.2 & 33.1 & 23.2 & 20.9 & 21.8 & 24.7 & 37 & 51.7 & 65.8 \\
\hline Radation & 1972 & 2638 & 3555 & 4500 & 5527 & 6361 & 6388 & 5888 & 4972 & 3527 & 2472 & 1888 \\
\hline Cloud(octa) & 4 & 4.1 & 3.7 & 3.6 & 2.6 & 1.2 & 0.8 & 0.9 & 1 & 2.2 & 3 & 3.8 \\
\hline
\end{tabular}


Table 5: Mean Monthly values of meteorological parameters and Wind Power Density for Talafar station at $10 \mathrm{~m}$ height for the period $(1980$ - 2010)

\begin{tabular}{|c|c|c|c|c|c|c|c|c|c|c|c|c|}
\hline $\begin{array}{c}\text { Mon. } \\
\text { Met. el . }\end{array}$ & JAN & FEB & MAR & APR & MAY & JUN & JUL & AUG & SEP & OCT & NOV & DEC \\
\hline $\mathrm{WPD}\left(\mathrm{w} / \mathrm{m}^{2}\right)$ & 33.2 & 41.7 & 48.1 & 55.1 & 80.3 & 80.3 & 95.3 & 90.1 & 71.2 & 48.1 & 38.7 & 36 \\
\hline $\mathrm{V}(\mathrm{m} / \mathrm{s})$ & 3.8 & 4.1 & 4.3 & 4.5 & 5.1 & 5.1 & 5.4 & 5.3 & 4.9 & 4.3 & 4 & 3.9 \\
\hline $\begin{array}{c}\text { Sun } \\
\text { hhine(hr) }\end{array}$ & 5.1 & 5.5 & 6.9 & 7.9 & 9.8 & 12.1 & 12.2 & 11.4 & 10 & 8.1 & 6.1 & 5 \\
\hline Pressure(mb) & 1024 & 1021.4 & 1018.6 & 1015 & 1012 & 1006 & 1001.6 & 1003.7 & 1010 & 1017 & 1020 & 1021 \\
\hline Tmean( $\left.\mathrm{C}^{\circ}\right)$ & 7.1 & 8.3 & 12.4 & 18.6 & 26.5 & 30.9 & 35 & 32.8 & 30.4 & 23.3 & 14 & 8.7 \\
\hline RH\% & 76 & 70 & 61 & 54.6 & 37 & 23 & 22 & 23.1 & 24 & 36 & 58 & 73 \\
\hline Radation & 1899 & 2504 & 3510 & 4368 & 5283 & 6072 & 6011 & 5518 & 4525 & 3272 & 2269.7 & 1801.7 \\
\hline Cloud(octa) & 4.4 & 4 & 3.7 & 3.3 & 2.8 & 1.2 & 0.84 & 0.6 & 1 & 2.4 & 3.3 & 4.3 \\
\hline
\end{tabular}

Wind Power Density may be estimated as:

$$
\mathrm{WPD}=\frac{1}{2} \rho \mathrm{V}^{3}
$$

Where

$\rho=$ is the air density

$\rho=1.225 \mathrm{~kg} / \mathrm{m}^{3}$ at average atmospheric pressure at sea level and $15 \mathrm{C}^{0}$.

Air density depends on altitude, air pressure and temperature.

Air density can be computed from the following equation:

$$
\rho=1.225-\left(1.19 \times 10^{-4} \times Z\right)
$$

where $Z=$ the location's elevation above sea level in $(\mathrm{m})$.

$\mathrm{V}=$ is the monthly mean wind speed.

In our paper the air density assumed to be $1.225 \mathrm{~kg} / \mathrm{m}^{3}$ as mentioned in many papers. The mean monthly values of wind power density for the different stations were computed using equation (1), and listed in tables (Rehmam, 2013; Kidmo, 2015; Klumpner, 2010; Barthlmie, 2010). In order to estimate the wind power density at height $(20,30,40,50,60) \mathrm{m}$. power law must be used to estimate the wind speed at these heights. The power law which predicts the wind speed as function of a latitude expressed as:

$\mathrm{V}_{\mathrm{h}} / \mathrm{V}_{\mathrm{a}}=\left(\mathrm{Z}_{\mathrm{h}} / \mathrm{Z}_{\mathrm{a}}\right)^{\alpha}$

Where

$\mathrm{V}_{\mathrm{h}}=$ is the wind speed in $\mathrm{m} / \mathrm{s}$ at normalized height $\mathrm{Z}_{\mathrm{h}}(10 \mathrm{~m})$.

$\mathrm{V}_{\mathrm{a}}=$ is the wind speed in $\mathrm{m} / \mathrm{s}$ at height $\mathrm{Z}_{\mathrm{a}}$ in $\mathrm{m}$.

$\alpha=$ is an exponent which depend on surface roughness and atmospheric stability. The most frequently adopted value of $\alpha$ is (1/7) (Patel, 2005).

A number of regression models (Linear, Quadratic, Logarithmic, Linear Logarithmic, power) were used to investigate and validated to estimate the mean monthly wind power density using different meteorological parameters in the four stations.

In order to select the best model, Coefficient of variation (R). Coefficient of determination $\left(\mathrm{R}^{2}\right.$ ), Mean Absolute Error ( MAE ), Root Mean Square Error (RMSE) were used. 
RESULTS AND DISCUSSION

Fig. (2) shows the correlations between the Wind Power Density and the Sunshine (n) in all stations. Liner Models is the best fit for all stations. The coefficient of determination ( $\mathrm{R}^{2}$ ) exist between (WPD and $n$ ) ranged between $(0.72-0.93)$, this mean that (72\% - 93\%) of WPD can be accounted using the mean monthly (n). This implies that there are statistically significant relationship between (WPD and $n$ ).

Fig. (3) shows the correlations between the Wind Power Density and atmospheric pressure (P)in all stations. Liner Model is the best fit for all stations. The coefficient of determination $\left(\mathrm{R}^{2}\right)$ exist between (WPD and P.) ranged between $(0.90-0.99)$. This mean that the correlations is highly acceptable in all stations.

Fig. (4) shows the correlations between the Wind Power Density and Cloudiness (C) in all stations. It can be seen that the coefficient of determination $\left(\mathrm{R}^{2}\right)$ between ( WPD and $\mathrm{C}$ ) is low in Mosul, Rabea and Sinjar stations and ranged between (0.35 -0.55) while in Talafar it reach (0.79). This mean that the correlations are not Statistically Significant in all stations except in Talafr station.

Fig. (5) shows the correlations between Wind Power Density and Solar Radiation (R). Quadratic model is the best fit in all stations except in Mosul station where Logarithmic Model is the best fit. The correlations is highly acceptable in all stations where the coefficient of determination $\left(\mathrm{R}^{2}\right)$ are ranged between (0.84- 0.97$)$.

Fig. (6) shows the correlations between Wind Power Density and Relative Humidity $(\mathrm{R} \mathrm{H})$ in all stations. Linear Model is the best fit in all stations except in Sinjar station, where as Quadratic model is the best fit.

The coefficient of determination $\left(\mathrm{R}^{2}\right)$ exist between (WPD and R.H) ranged between $(0.7-$ 0.8 ), for all stations except in Rabea station which give a weak correlations.

Fig. (7) shows the correlations between Wind Power Density and air temperature (T) Linear Model is the best fit in all stations except in Talafr station where quadratic model is the best fit. The coefficient of determination $\left(\mathrm{R}^{2}\right)$ exist between (WPD and T) ranged between $(0.6-0.76)$ for all stations except in Talafr station where $\left(\mathrm{R}^{2}\right)$ equal to $(0.91)$. A Highly acceptable correlations were obtained between Wind Power Density and Height as shown in Fig.(8)where the values of $\left(\mathrm{R}^{2}\right)$ are arranged between $(0.93-0.96)$ in all stations. 

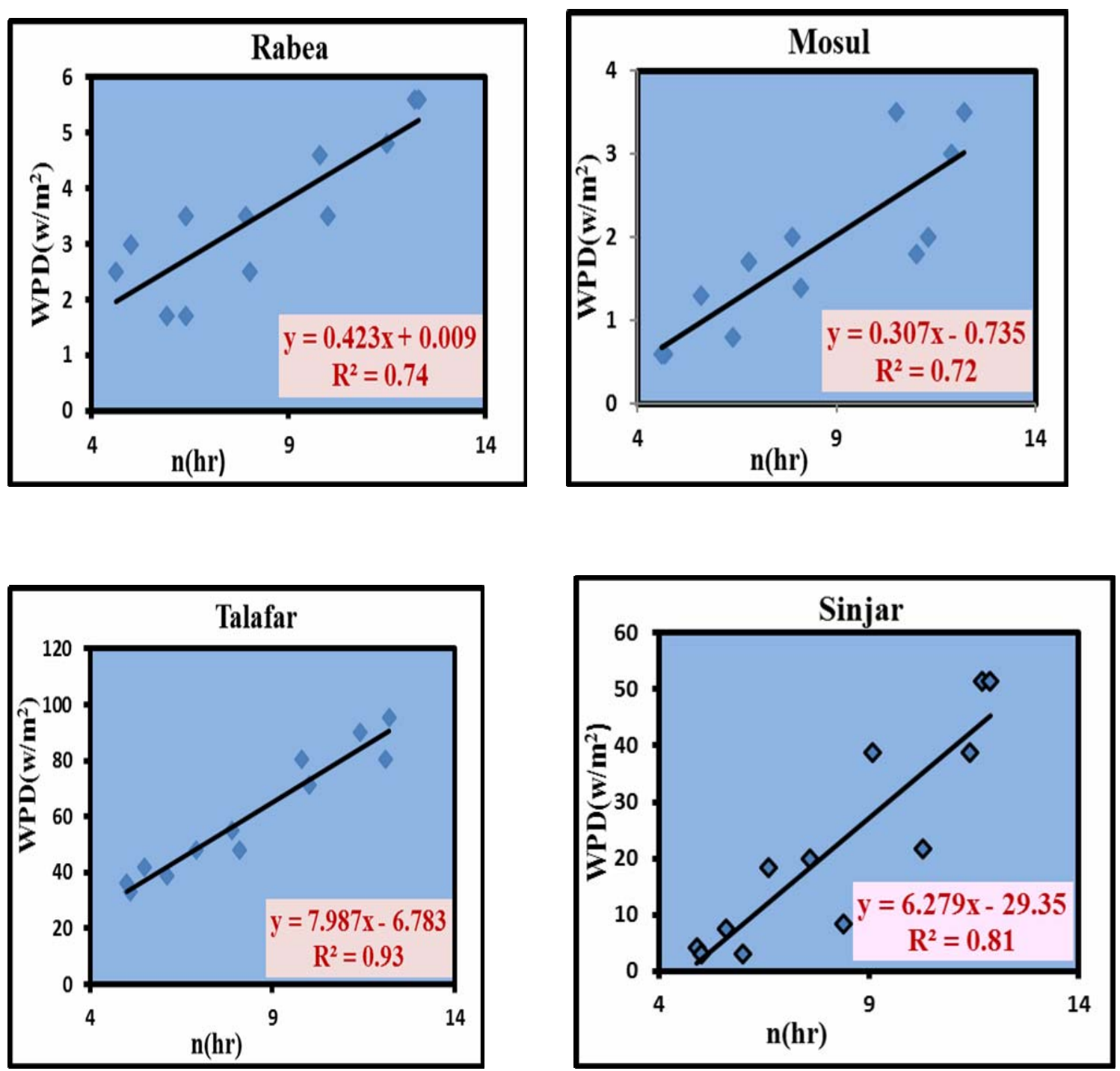

Fig. 2: Correlation between the wind power density and sunshine for all stations in Nineveh Governorate 

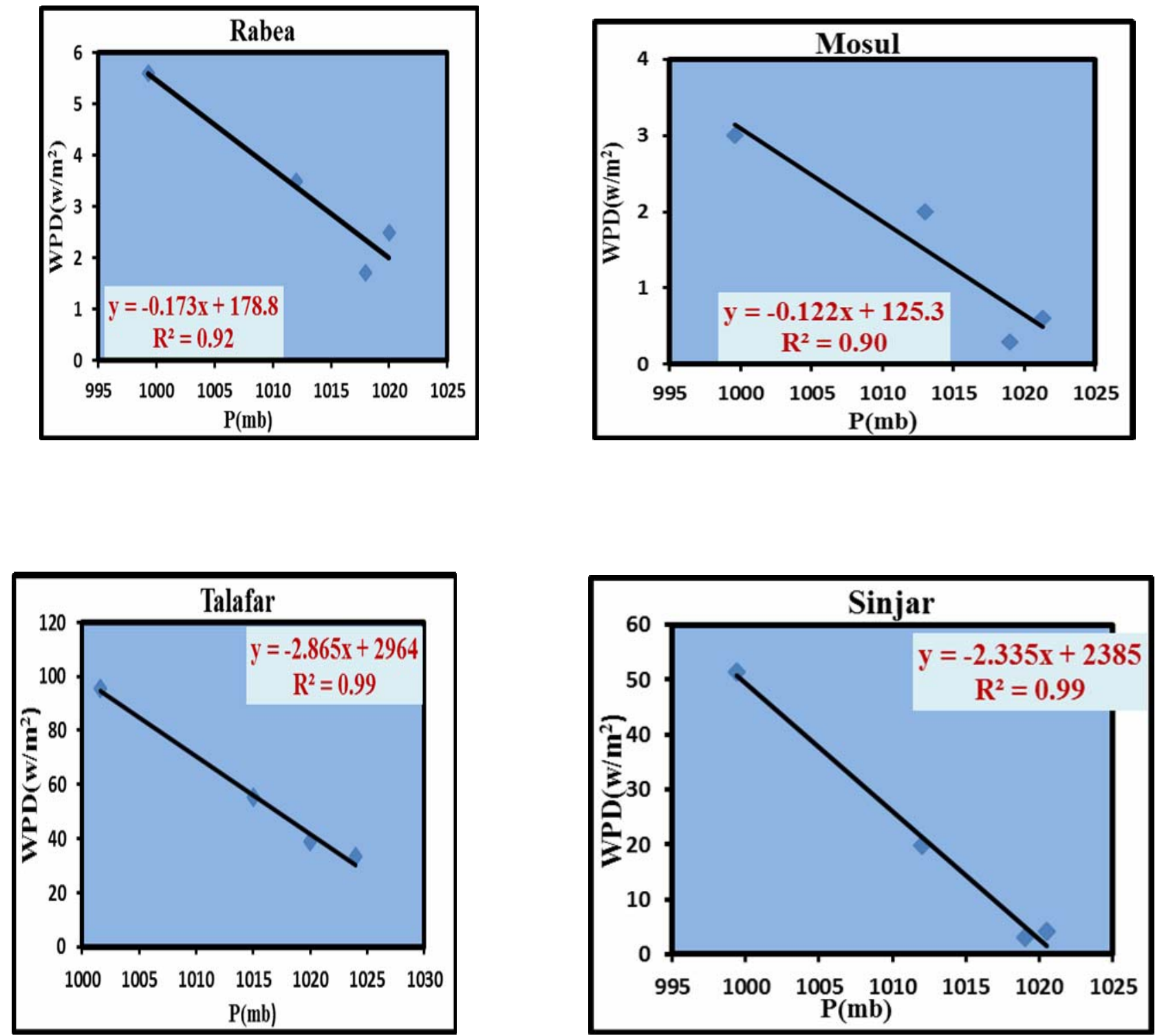

Fig. 3: Correlation between the wind power density and pressure for all stations in Nineveh Governorate 

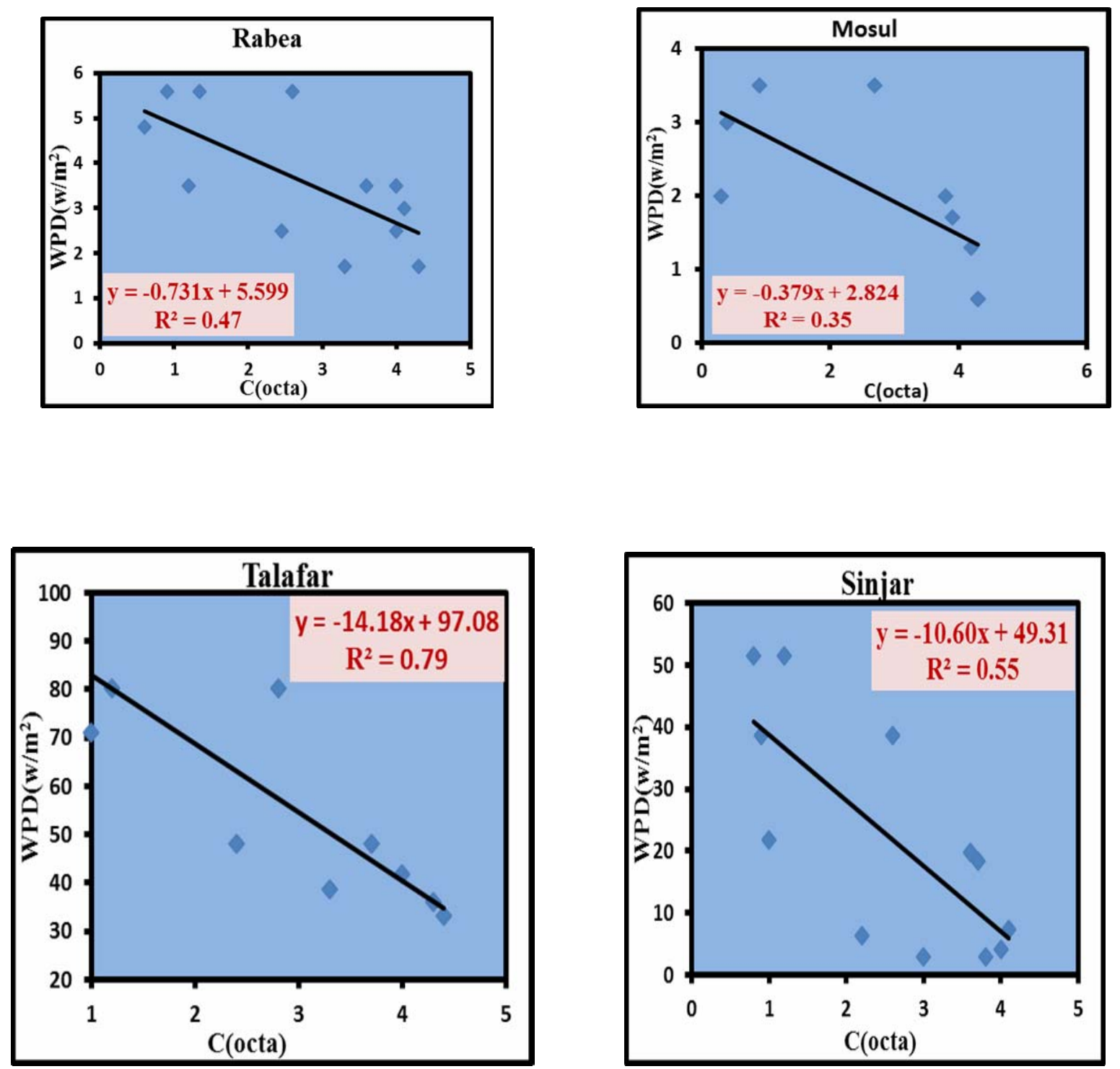

Fig. 4: Correlation between the wind power density and cloudiness for all stations in Nineveh Governorate. 

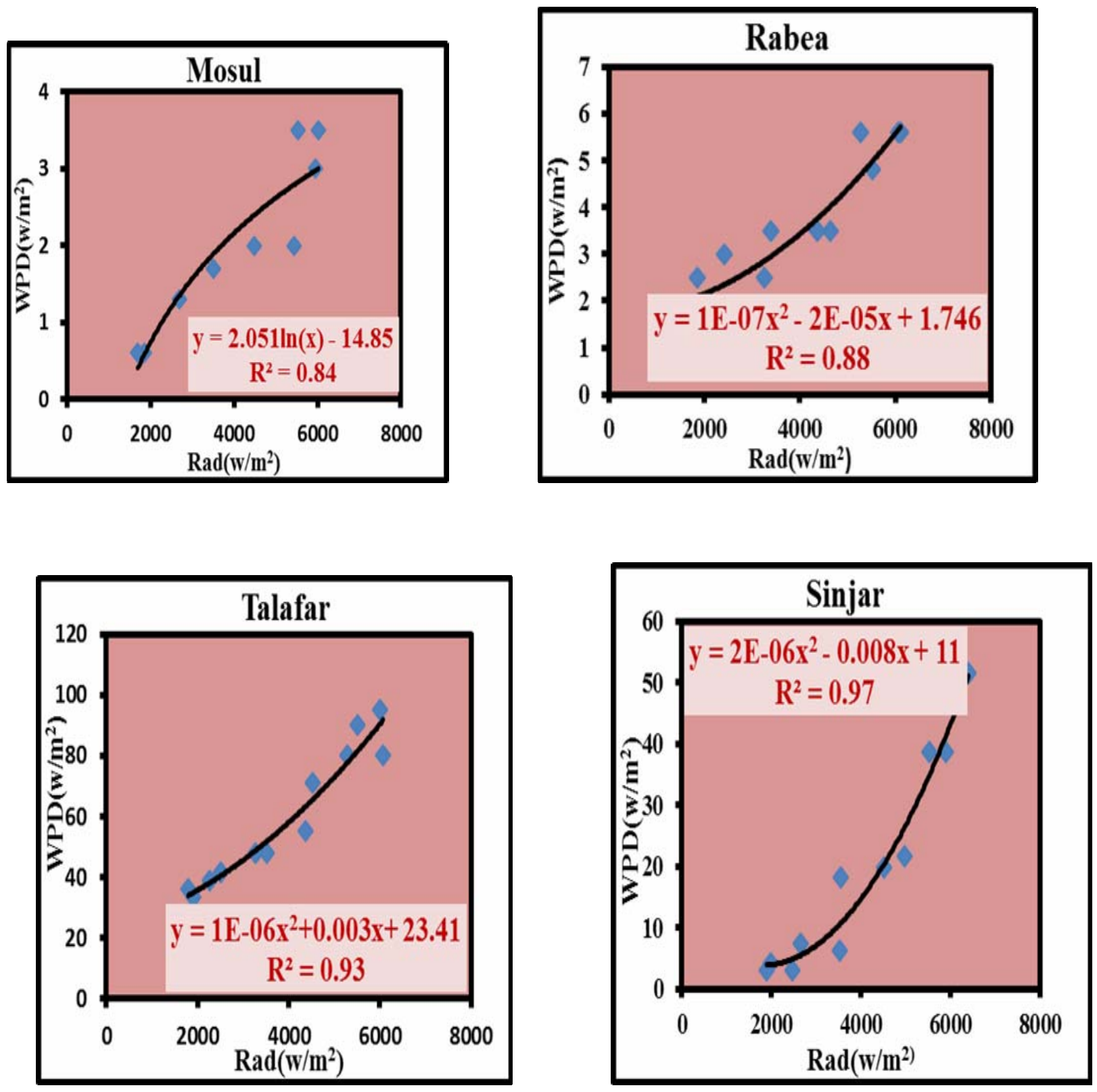

Fig. 5: Correlation between the wind power density and radiation for all stations in Nineveh Governorate 

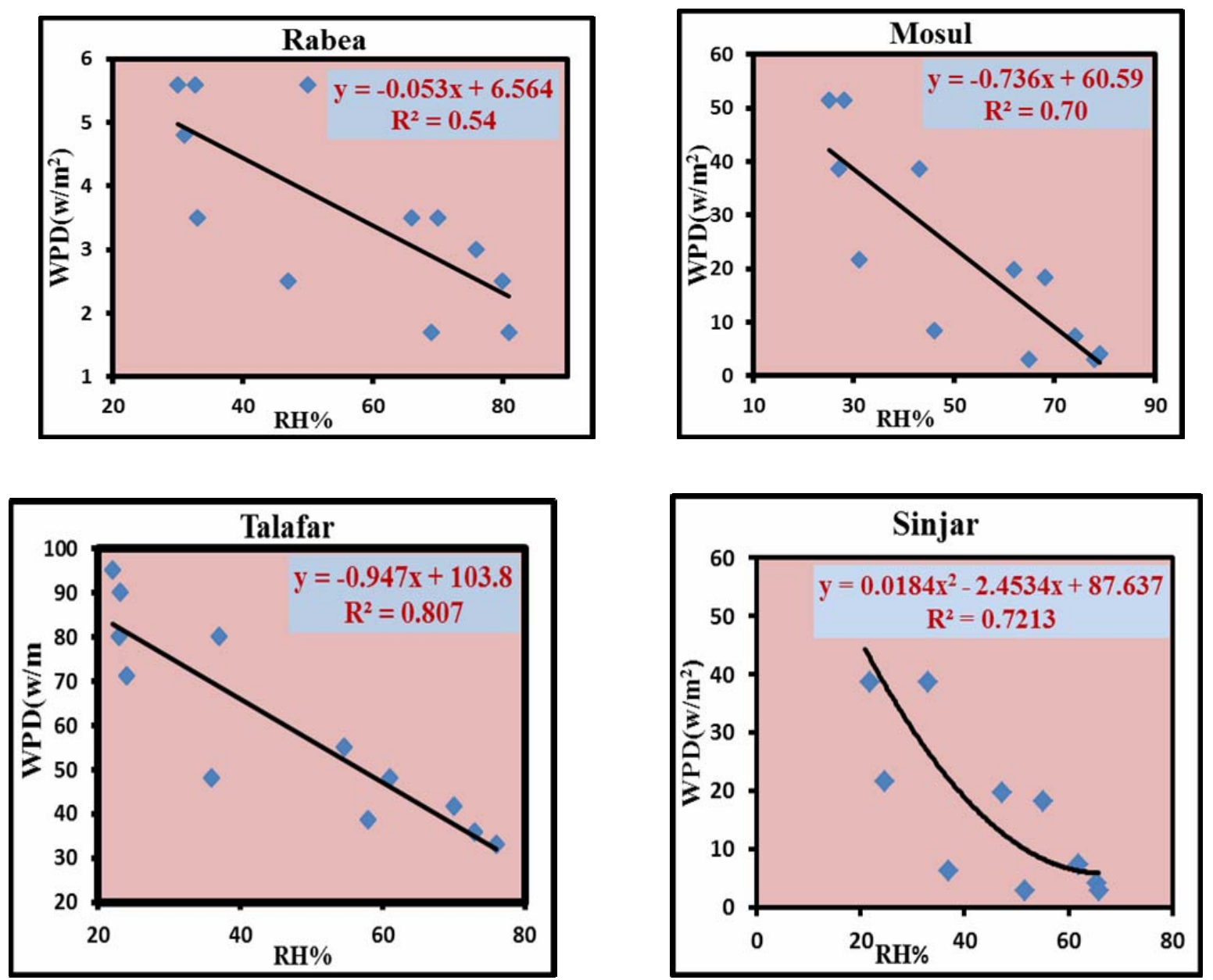

Fig. 6: Correlation between the wind power density and relative humidity for all stations in Ninava Governorate. 

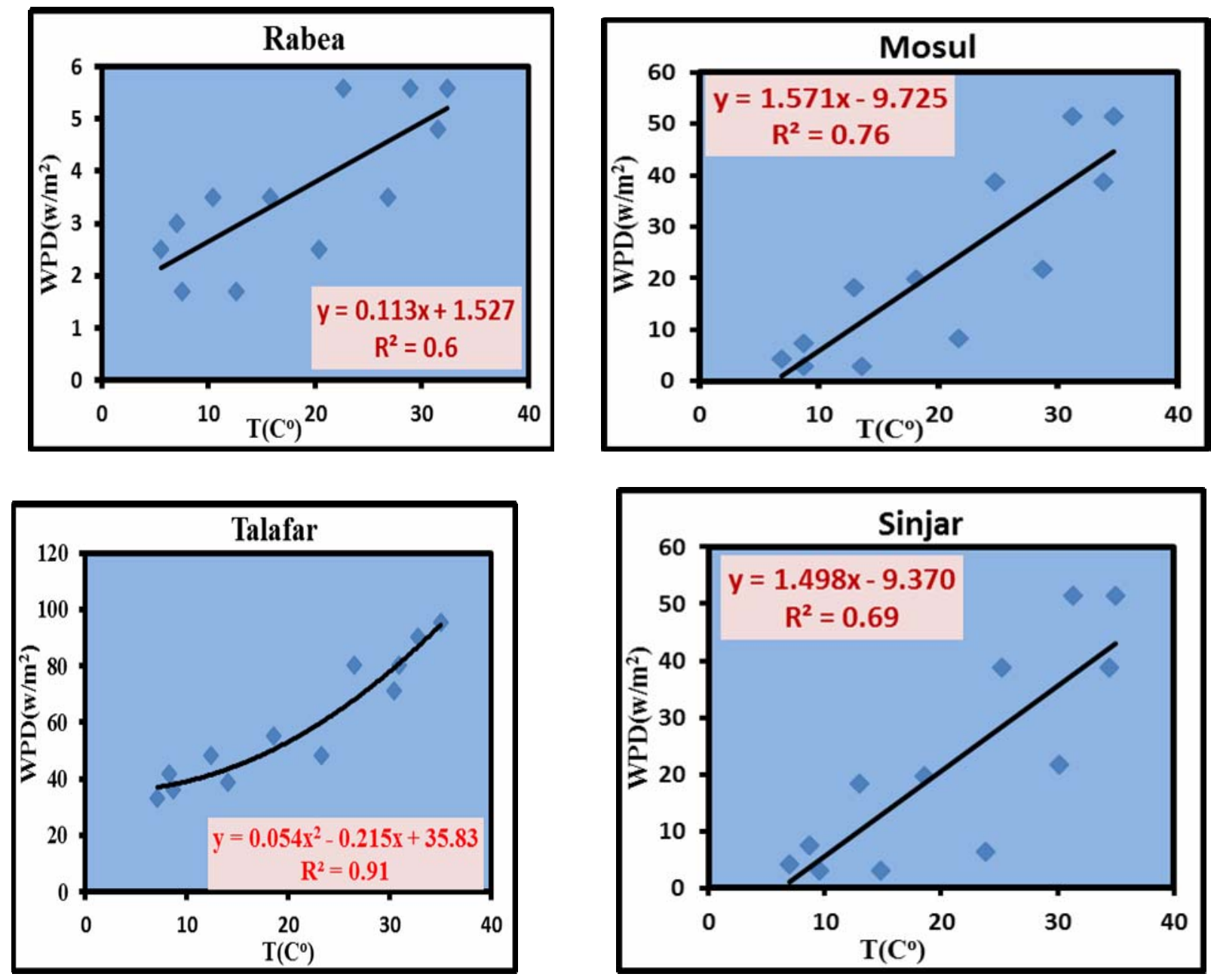

Fig. 7: Correlation between the wind power density and air temperature for all stations in Nineveh Governorate. 

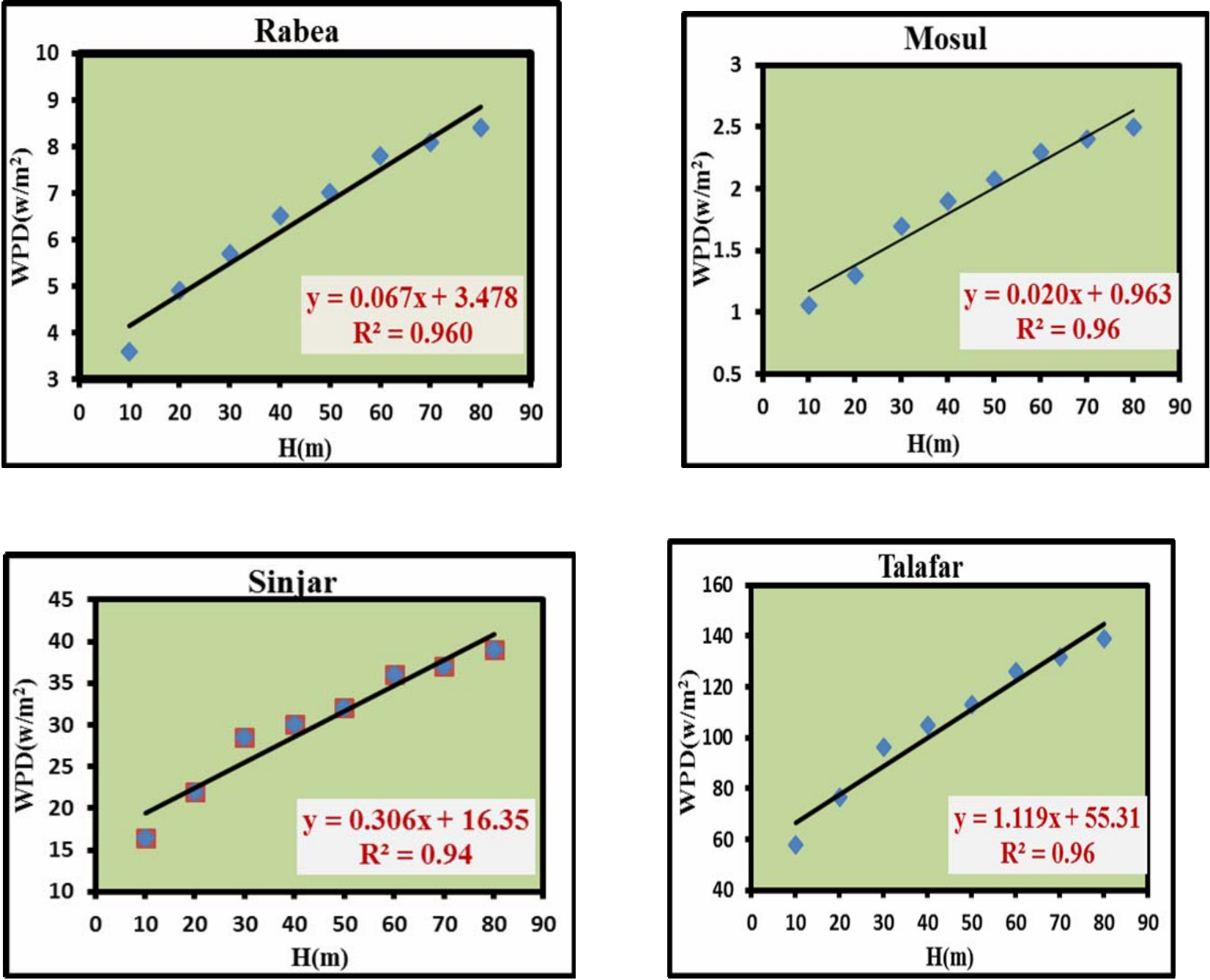

\section{Fig. 8: Correlation between the wind power density and height for all stations in Nineveh} Governorate

Table (6) contain Summaries of regression statistics obtained from the different models in all stations. The correlation coefficient $(\mathrm{R})$, coefficient of determination $\left(\mathrm{R}^{2}\right)$, Mean Absolute Error M.A.E ) and Root Mean Square Error ( RMSE ) varies from one station to another, and also vary from one variable to another.

The lowest values of MAE (2.7- 6.4) \% was obtained in the correlations between WPD and elevation. This indicate that these correlations are highly acceptable for the estimation of WPD in all stations. MAE is found in the range (7- 25) \% for the correlations between (WPD and $n$ ) and in the range (4-16.5) \% for the correlations between (WPD and P) and in the range (8.3-21)\%for the correlations between (WPD and Rad) and in the range $(9-35) \%$ for the correlations between (WPD and T). This mean that there are Statistically Significant relationship between WPD and $(\mathrm{n}, \mathrm{Rad}, \mathrm{P}, \mathrm{T})$ in all stations.

A fairly good fitting was obtained between WPD and RH. The highest value of MAE was obtained in the correlations between WPD and C in Mosul and Sinjar stations, where its values are $(115-110) \%$ respectively. This mean that these correlations are non significant. RMSE show acceptable values for the correlations between WPD and (n, Rad, P, RH,T) in all stations. High values of RMSE was obtained for the correlations between WPD and $\mathrm{C}$ in Mosul and Sinjar stations, where its values are $(177$ - 300) \% respectively. A according to the Statistical tests $\left(\mathrm{R}, \mathrm{R}^{2}\right.$, MAE, RMSE) we can arrange the correlations between WPD and the 
different meteorological parameters according to their best fit as:

1-WPD and Height 2-WPD and P 3-WPD and Rad 4-WPD and $n$ 5-WPD and T 6-WPD and RH 7-WPD and C

Table 6: Summaries of Regression Statistics obtained from the different models in all stations

\begin{tabular}{|c|c|c|c|c|c|}
\hline Stations & Correlation WPD and $n$ & $\mathbf{R}$ & $\mathbf{R}^{2}$ & \%МAE & \%RMSE \\
\hline Mosul & $W P D=0.307 n-0.735$ & 0.85 & 0.72 & 17 & 22 \\
\hline Rabea & $\mathrm{WPD}=0.423 n+0.009$ & 0.86 & 0.74 & 25 & 31 \\
\hline Sinjar & $\mathrm{WPD}=6.279 \mathrm{n}-29.35$ & 0.90 & 0.81 & 17.4 & 24.6 \\
\hline Talafar & $W P D=7.987 n-6.783$ & 0.96 & 0.93 & 7 & 8.9 \\
\hline Stations & Correlation WPD and P & $\mathrm{R}$ & $\mathrm{R}^{2}$ & $\% \mathrm{MAE}$ & $\%$ RMSE \\
\hline Mosul & $\mathrm{WPD}=-0.122 \mathrm{P}+125.3$ & 0.94 & 0.90 & 14 & 14.8 \\
\hline Rabea & $W P D=-0.173 P+178.8$ & 0.95 & 0.92 & 11 & 15.5 \\
\hline Sinjar & $W P D=-2.335 P+2385$ & 0.99 & 0.99 & 16.5 & 25 \\
\hline Talafar & $W P D=-2.865 P+2964$ & 0.99 & 0.99 & 4 & 5.3 \\
\hline Stations & Correlation WPD and C & $\mathrm{R}$ & $\mathrm{R}^{2}$ & $\% \mathrm{MAE}$ & $\%$ RMSE \\
\hline Mosul & $\mathrm{WPD}=-0.379 \mathrm{C}+2.824$ & 0.59 & 0.35 & 115 & 177.8 \\
\hline Rabea & $\mathrm{WPD}=-0.731 \mathrm{C}+5.599$ & 0.68 & 0.47 & 27 & 34 \\
\hline Sinjar & $\mathrm{WPD}=-10.6 \mathrm{C}+49.31$ & 0.74 & 0.55 & 110 & 300 \\
\hline Talafar & $\mathrm{WPD}=-14.18 \mathrm{C}+79.08$ & 0.88 & 0.79 & 10.8 & 15.5 \\
\hline Stations & Correlation WPD and Rad & $\mathrm{R}$ & $\mathrm{R}^{2}$ & $\% \mathrm{MAE}$ & \%RMSE \\
\hline Mosul & $\mathrm{WPD}=2.051 \ln (\mathrm{R})-14.85$ & 0.92 & 0.84 & 13.6 & 18.4 \\
\hline Rabea & $\mathrm{WPD}=1 \mathrm{E}-07 \mathrm{R}^{2}-2 \mathrm{E}-05 \mathrm{R}+1.746$ & 0.93 & 0.88 & 14 & 16.6 \\
\hline Sinjar & $W P D=2 E-06 R^{2}-0.008 R+11$ & 0.98 & 0.97 & 21 & 26.6 \\
\hline Talafar & $\mathrm{WPD}=1 \mathrm{E}-06 \mathrm{R}^{2}+0.003 \mathrm{R}+23.41$ & 0.96 & 0.93 & 8.3 & 19 \\
\hline Stations & Correlation WPD and $\mathrm{RH} \%$ & $\mathrm{R}$ & $\mathrm{R}^{2}$ & $\% \mathrm{MAE}$ & $\%$ RMSE \\
\hline Mosul & $\mathrm{WPD}=-0.736 \mathrm{RH}+60.59$ & 0.83 & 0.7 & 68 & 78 \\
\hline Rabea & $\mathrm{WPD}=-0.053 \mathrm{RH}+6.564$ & 0.74 & 0.54 & 25 & 32 \\
\hline Sinjar & $\mathrm{WPD}=0.018 \mathrm{RH}^{2}-.45 \mathrm{RH}+87.6$ & 0.85 & 0.72 & 33 & 37 \\
\hline Talafar & $\mathrm{WPD}=0.947 \mathrm{RH}+103.8$ & 0.89 & 0.81 & 12 & 17 \\
\hline Stations & Correlation WPD and T & $\mathrm{R}$ & $\mathrm{R}^{2}$ & $\% \mathrm{MAE}$ & $\%$ RMSE \\
\hline Mosul & $\mathrm{WPD}=1.5171 \mathrm{~T}+9.725$ & 0.87 & 0.76 & 27.8 & 38 \\
\hline Rabea & $\mathrm{WPD}=0.113 \mathrm{~T}+1.527$ & 0.77 & 0.6 & 25 & 31 \\
\hline Sinjar & $\mathrm{WPD}=1.498 \mathrm{~T}-9.37$ & 0.83 & 0.69 & 35 & 43 \\
\hline Talafar & $\mathrm{WPD}=0.054 \mathrm{~T}^{2}+0.215 \mathrm{~T}+35.83$ & 0.95 & 0.91 & 9 & 10.8 \\
\hline Stations & Correlation WPD and $\mathrm{H}$ & $\mathrm{R}$ & $\mathrm{R}^{2}$ & $\% \mathrm{MAE}$ & $\%$ RMSE \\
\hline Mosul & $\mathrm{WPD}=0.02 \mathrm{H}+0.963$ & 0.98 & 0.96 & 2.7 & 3.5 \\
\hline Rabea & $\mathrm{WPD}=0.067 \mathrm{H}+3.478$ & 0.98 & 0.96 & 4.3 & 4.9 \\
\hline Sinjar & $\mathrm{WPD}=0.306 \mathrm{H}+16.36$ & 0.97 & 0.94 & 4.4 & 6.4 \\
\hline Talafar & $\mathrm{WPD}=1.119 \mathrm{H}+55.31$ & 0.98 & 0.96 & 4.1 & 4.5 \\
\hline
\end{tabular}




\section{CONCLUSION}

The Wind Power Density for all meteorological stations in Ninava Governorate has been expressed of (Sunshine, Solar Radiation, Height, Air pressure, Air Temperature, Relative Humidity, Cloudiness ) applying a variety of Regression Models .

The Significance and Performance Characteristics of the Models have been viewed using several statistical tests ( $\mathrm{R}, \mathrm{R}^{2}$, MAE, RMSE).

The results showed that the best correlation was obtained WPD and Height followed by WPD and atmospheric Pressure, then WPD and Solar Radiation, then WPD and Sunshine, then WPD and Air Temperature, after that WPD and Relative Humidity. A weak correlation was obtained between WPD and Cloudiness.

Linear Models give the best fit for the relation between WPD and (n, H, P, C) in all stations.

Quadratic Model and Linear Model gave the best fit between WPD and (Rad, RH, T) in all stations. Logarithmic Model give the best fit between WPD and Rad in Mosul station.

\section{REFERENCES}

Abdul Kareem, M.S. (2015). Theoretical study of temperature effect on the wind power extracted as a renewable energy for electricity production in Nassiriyah district. JCBPS, section D. 5(2),1958-1966.

Barthlmie, R.J.; Sempreviva, A. M.; Pryor, S.C. (2010). The influence of humidity fluxes on offshore wind speed profile. Ann. Geophys. 28, 1043-1052.

Kidmo, D.K.; Danwe, R.; Doka, S.Y.; Djongyany, N. (2015). Statistical analysis of wind speed distribution boyedon Six Weibull Methods for wind power evaluation in Garoua, Cameroon. Revue de Energies Renouvelables.

Klumpner, D.C.; Hann, D.B. (2011). Effect of rain on vertical axis wind turbine, International Conference on renewable energies and power quality. (Spain), $13^{\text {th }}$ to $1 \mathrm{~S}^{\text {th }}$ April 2011.

Nolan, P.; Lynch, P.; McGrath, R.; Semmler, T.; Warys (2011). Simulating climate change and its effect on the wind energy rescuer of Ireland. Wind Energy., 15, 593- 608.

Ohnakin, O.S.; Adaramola, M.S.; Oyewola, O.M. (2010). Wind energy evaluation for electricity generation using WECS in seven selected location in Nigeria. 88(9), 3197-3206.

Patel, M.R. (2005). "Wind and Solar Power Systems Design, Analysis and Operation". CRC Press.

Perkevic, L.; Silva, P.; Ban, M.; Kranjcevic, N.; Duic, N. (2013). Harvesting high altitude wind energy for power production. Applied Energy. 101, 151- 160

Rehmam, S. (2013). Long term wind speed analysis and detection of its trends using Mann. Kendall Test and Linear Regression Method. AJSE., 38(2), 421- 437. 